\title{
Petrographical and geomechanical assessment of Widikum and its surroundings' geological formations (North-West Cameroon) as construction materials
}

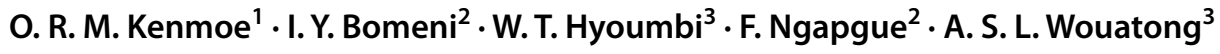

Received: 7 April 2020 / Accepted: 5 October 2020 / Published online: 25 November 2020

(c) Springer Nature Switzerland AG 2020

\begin{abstract}
Widikum and its surroundings (North-West Cameroon) are covered with basalts, granites and gneisses. Construction companies use these rocks extensively and indiscriminately for structural loading, pavements, wall cladding as cobblestone and masonry stones. The suitability of these rocks and their petrographic (outcrops mode, structure, color, mineralogical composition and crystals size), physical and geomechanical (specific density, bulk density, Los Angeles abrasion test, and Aggregates crushing test) properties evaluation becomes important for their aforementioned applications. The aim of this study is to characterize on the petrographic and geomechanical level, basalts, granites and gneisses of the locality of Widikum and its surroundings for their use as construction materials. Concerning the petrographical point, granites and gneisses are rich in quartz, feldspar, plagioclase, biotite, amphibole and accessory minerals like opaque minerals and zircon. On the other hand, basalts are ferro-magnesians rich in olivine, pyroxene and opaque minerals. Plagioclase is also a main constituent mineral of this geological formation. On the physical and geomechanical properties, despite their extension on the field, granites have satisfactory density; but, they are least resistant according to the Los Angeles abrasion values. However, basalts are one of the geological formations which are the least extended on the field. They are most dense with the satisfactory to excellent Los Angeles abrasion values. Concerning the gneissic formation, its density and Los Angeles abrasion values are satisfactory. Generally, the aggregates crushing values of studied geological formations attest that they are satisfactory to excellent apart from those of coarse grainy granites. In view of the foregoing, basalts have the best geomechanical qualities and could be used as constituent of construction materials.
\end{abstract}

Keywords Widikum · Geological formations · Geomechanical properties · Construction materials

\section{Introduction}

The used of geomaterials in building construction are increased due to the exponential grow of demography which is evidenced by unparallel expansion and upgradation of infrastructures such as highways, airports, schools, hospitals, publics and private buildings [1]. According to the anthropic environment, it is necessary to investigate the concept of degradation of rocks in order to provide appropriate responses to the problems of conservation and restoration of these materials [2]. The road network can be taken as an indicator of the development of any society since it facilitates the movement of the humans and their thinks, therefore their having a direct impact on increase economic [3]. In this context, the road network has the obligation to ensure the adequate conditions of

O. R. M. Kenmoe, michkenmoe@gmail.com | 'Department of Mining Engineering, School of Geology and Mining Engineering, University of Ngaoundere, P.O Box 115, Meiganga, Cameroon. ${ }^{2}$ Department of Civil Engineering, Fotso Victor Institute of Technology, University of Dschang, P.O Box 67, Dschang, Cameroon. ${ }^{3}$ Department of Earth Sciences, Faculty of Science, University of Dschang, P.O Box 67, Dschang, Cameroon. 
movement from the point of view of road safety, comfort and efficiency of transport [4]. The lifespan of buildings depends also on the quality of rocks aggregates. Rocks aggregates are materials which enter into the composition of concrete and bituminous mixes for road pavements and railroad ballasts, coming either from natural materials (residual formations), or from crushing massive rocks (eruptive, metamorphic or sedimentary rocks) [5]. The physical and mechanical properties of rocks have a great influence on the stability of the ground. The characterization of a rock mass is based on the identification of its physical-mechanical properties in the field and in the laboratory [6]. The mechanical behavior of rock massifs is a determining factor in the dimensioning of the works executed there [6]. The quality of the aggregate is directly conditioned by the petrographic nature (mineralogical composition and texture) of the rock and the method of preparation of the aggregates [5].

\section{Geographic and geological setting}

\subsection{Location of the study area}

The Widikum locality and its surroundings in which the present study was carried out are situated in the North-West Region of Cameroon. It belongs to the great geographical whole of the west Cameroon highlands exactly on the western slope of the Bambouto mountain. The perimeter of the study area is located between latitudes $05^{\circ} 49^{\prime} 12^{\prime \prime}$ and $05^{\circ} 54^{\prime} 12^{\prime \prime}$ of the Northern hemisphere and longitude $9^{\circ} 42^{\prime} 00^{\prime \prime}$ to $9^{\circ} 50^{\prime} 00^{\prime \prime}$ East (Fig. 1).

\subsection{Geological setting}

The Bamenda mountain is located in the Bambouto mountain prolongation. It constitutes a corridor from 15 to $20 \mathrm{~km}$ directed $40^{\circ} \mathrm{NE}$, materialized by a succession of tops bordered by the plains of Bamenda and Ndop. It is limited to the north by the basaltic plate of Nkambe and the Oku mountain, in the east by the Ndop plain (Noun basin), in the south by the Bambouto mountain and the west by the prolongation of the basaltic plate of Grassfield [7]. The study area and its surroundings are covering by the volcanic, plutonic and metamorphic rocks (Fig. 2) and belongs to the Bamenda mountain pertaining to the volcanic line of Cameroon (LVC). The LVC is a volcano-tectonics megastructure with a length of $1600 \mathrm{~km}$. Volcanism along the LVC started during Eocene with the installation of the Bamoun plate between 58.1 and $46.7 \mathrm{Myr}$ [8] and the Bangou mountain between 44.7 and 43.1 Myr [9]. This volcanism is still active following the example of Cameroon mountain (1999 and 2000). The Bamenda mountain $(2621 \mathrm{~m})$ constitutes the fourth more significant mountain

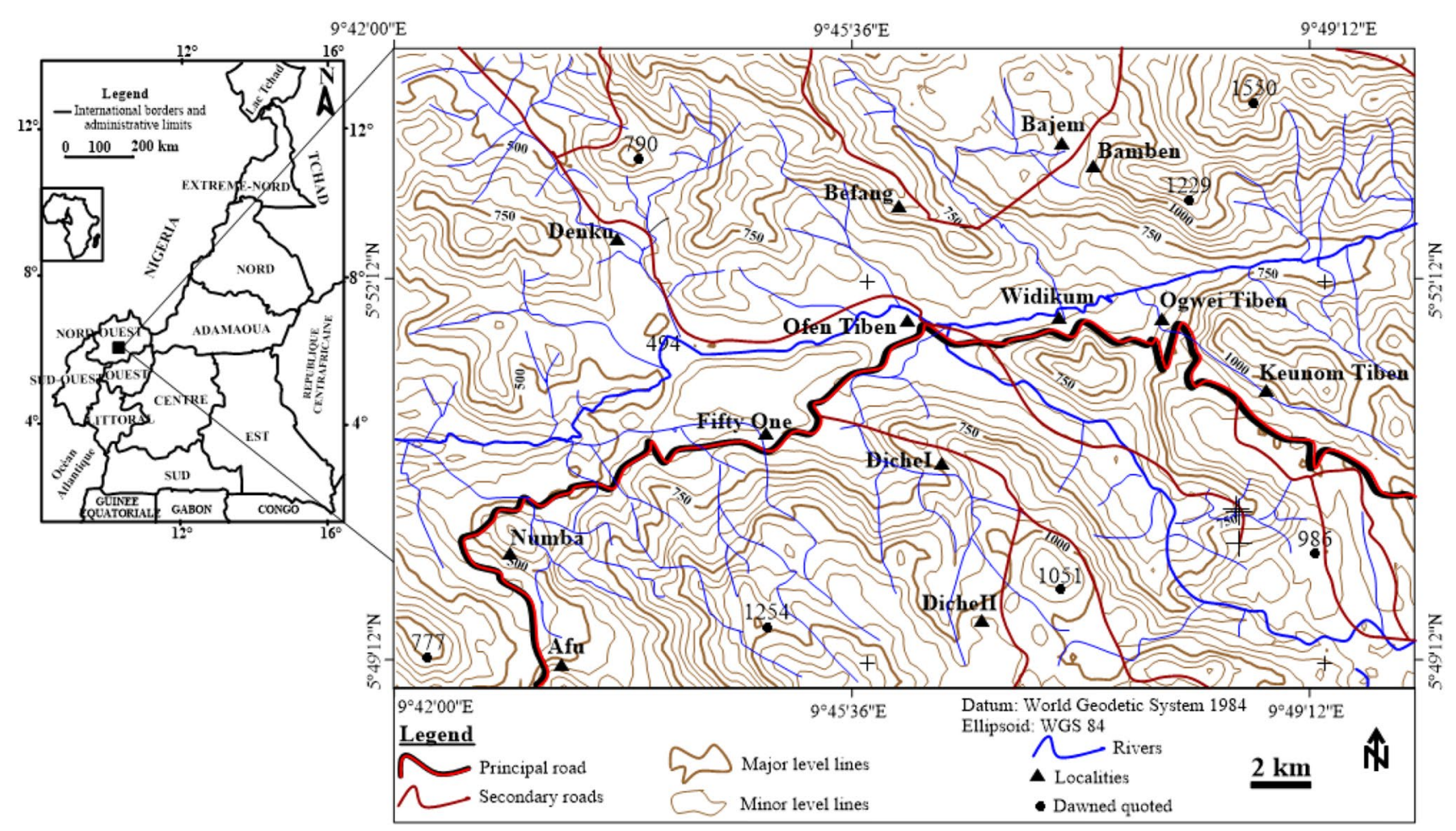

Fig. 1 Location of the study area 


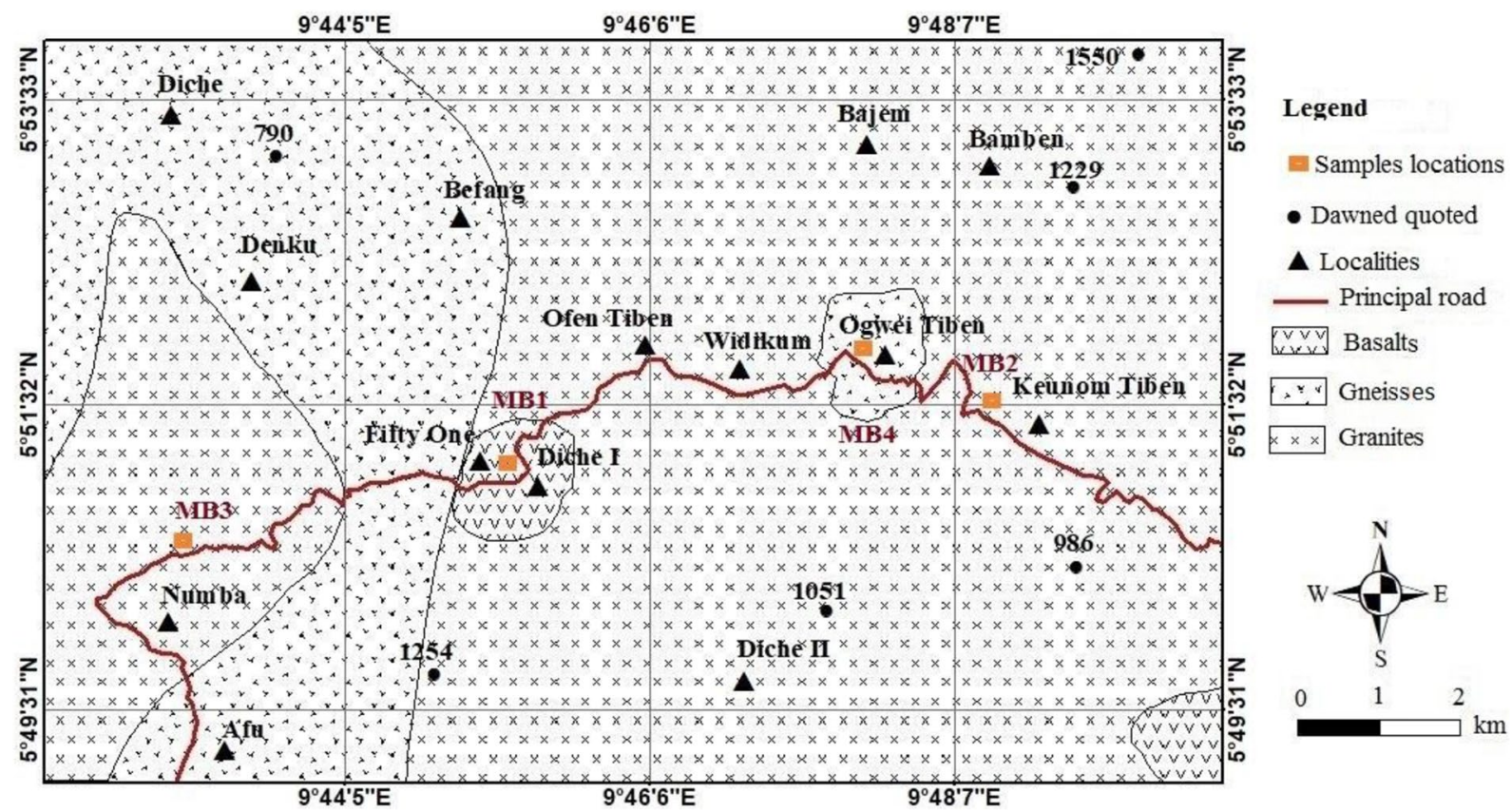

Fig. 2 Geological map of the study area

along the LVC after the Cameroon mountain (4095 m), Manengouba mountain ( $2411 \mathrm{~m}$ ) and Bambouto mountain $(2740 \mathrm{~m})$ [10].

The volcanological and petrological studies undertaken by Tchoua [11] on the Bamenda mountain shows that it is a volcano made up mainly of trachytes, basalts, and ignimbrites covering the crystalline basic complex made up with granites and gneisses. The petrographical and geochemical studies shows that the basic rocks are alkaline basanites, basalts, hawaiites and seldom mugearites whereas the acid types are trachytes, rhyolites, as well as the vast ones extended from ignimbrites and tuffs [12]. These rocks form a bimodal series basic and acid, the intermediary terms mugearite-benmoreite are rare [12]. determines $\mathrm{K}-\mathrm{Ar}$ ages between 0 and 17.4 Myr in the basic rocks and between 18.68 and 27.4 Myr in the acid rocks. As a whole, the alkaline basanites and basalts are with titanomagnetite and diopside, olivine phenocrysts. Alkaline feldspar and biotite microlites are occasionally observed in some basanites.

\section{Types of rocks and experimental methods}

\subsection{Types of rocks}

The geological formations like basalts, granites and gneisses outcrops in the study area. Four samples $(M B 1$, $M B 2, M B 3, M B 4$ ) have been collected respectively to Fifty One, Keunom Tiben, Numba and Ogwei Tiben localities. $M B 1$ represents the basalts sample. $M B 2$ and $M B 3$ corresponds to granitic samples and $M B 4$ is gneiss sample.

\subsection{Petrographical analysis}

Macroscopic and microscopic petrographical analyses have been done. Macroscopic analysis on the field has concerning the identification of the outcrops mode, structure, color, mineralogical composition and crystals size of the rocks. Microscopic analysis was carried out of a thin section using a polarising microscope at the environmental geology laboratory of the Dschang University.

\subsection{Physical and Geomechanical analysis}

The physical and geomechanical analysis (specific density, bulk density, Los Angeles abrasion test and aggregates crushing test) was performed on a specimen collected and transported to the National Civil Engineering Laboratory (LABOGENIE) of Yaounde (Cameroon). The specific density 
Table 1 LA aggregates composition

\begin{tabular}{lllll}
\hline $\begin{array}{l}\text { Aggregate } \\
\text { size class } \\
(\mathrm{mm})\end{array}$ & $\begin{array}{l}\text { Meshes } \\
\text { sieve } \\
(\mathrm{mm})\end{array}$ & $\begin{array}{l}\text { Percentage } \\
\text { of aggre- } \\
\text { gates }(\%)\end{array}$ & $\begin{array}{l}\text { Mass of } \\
\text { aggregates } \\
(\mathrm{g})\end{array}$ & $\begin{array}{l}\text { Total mass of } \\
\text { aggregates } \\
(\mathrm{g})\end{array}$ \\
\hline $4 / 6.3$ & 5 & 60 & 3000 & 5000 \\
& 4 & 40 & 2000 & \\
$6.3 / 10$ & 8 & 60 & 3000 & 5000 \\
& 6 & 40 & 2000 & \\
$10 / 14$ & 12.5 & 40 & 2000 & 5000 \\
& 10 & 60 & 3000 & \\
$10 / 25$ & 20 & 40 & 2000 & 5000 \\
& 16 & & & \\
& 12.5 & 60 & 3000 & \\
& 10 & & &
\end{tabular}

Table 2 LA abrasive load according to the size of aggregates

\begin{tabular}{ll}
\hline $\begin{array}{l}\text { Aggregate size } \\
\text { Class }(\mathrm{mm})\end{array}$ & $\begin{array}{l}\text { Number of } \\
\text { abrasive } \\
\text { load }\end{array}$ \\
\hline $4 / 6.3$ & 7 \\
$6.3 / 10$ & 9 \\
$10 / 14$ & 11 \\
$10 / 25$ & 11 \\
$16 / 31.5$ & 12 \\
$25 / 50$ & 12 \\
\hline
\end{tabular}

is done in accordance with the standard NFP 18-554 and NFP 18-555 [13] by the successive weighing method using the pycnometers with liquid. It makes it possible to evaluate the density of the solid particles of a material deprived of its granular vacuums inters. The purpose of this test is to extract the air contained in the vacuums or pores from the grains and the vacuums contained between the material grains. The specific density is expressed by the formula 1

$d_{s}=\frac{m_{2}}{m_{1}+m_{2}-m_{3}}$

where $d_{s}$ represent the unit weight; $m_{1}, m_{2}$, and $m_{3}$ are different weights obtained after successive weighing during the test. Otherwise, the bulk density was determined by the hydrostatic balance method in accordance with the standard NFP 94-054 [14]. The principle of the method consists in determining the volume of a sample by the Archimedes push, which makes it possible to determine its density starting from the successive weighing of the sample. The bulk density is consequently obtained by bringing back the density of the sample to that of an equal volume of water. It defined by the formula 2 :
Table 3 MDE aggregates composition

\begin{tabular}{lllll}
\hline $\begin{array}{l}\text { Aggregate } \\
\text { size class } \\
(\mathrm{mm})\end{array}$ & $\begin{array}{l}\text { Meshes } \\
\text { sieve } \\
(\mathrm{mm})\end{array}$ & $\begin{array}{l}\text { Percentage } \\
\text { of aggre- } \\
\text { gates }(\%)\end{array}$ & $\begin{array}{l}\text { Mass of } \\
\text { aggregates } \\
(\mathrm{g})\end{array}$ & $\begin{array}{l}\text { Total mass of } \\
\text { aggregates } \\
(\mathrm{g})\end{array}$ \\
\hline $4 / 6.3$ & 5 & 60 & 300 & 500 \\
& 4 & 40 & 200 & \\
$6.3 / 10$ & 8 & 60 & 300 & 500 \\
& 6 & 40 & 200 & \\
$10 / 14$ & 12.5 & 40 & 200 & 500 \\
& 10 & 60 & 300 & \\
$10 / 25$ & 20 & 40 & 200 & 500 \\
& 16 & & & \\
& 12.5 & 60 & 300 & \\
& 10 & & &
\end{tabular}

Table 4 MDE mass of the balls according to the size of aggregates

\begin{tabular}{ll}
\hline $\begin{array}{l}\text { Aggregate size } \\
\text { Class }(\mathrm{mm})\end{array}$ & $\begin{array}{l}\text { Mass of } \\
\text { the balls } \\
(\mathrm{g})\end{array}$ \\
\hline $4 / 6.3$ & 2000 \\
$6.3 / 10$ & 3000 \\
$10 / 14$ & 5000 \\
\hline
\end{tabular}

$d_{a}=\frac{\rho_{h}}{\rho_{w}}$

$d_{a}$ represents the bulk density, $\rho_{h}$ the wet density and $\rho_{w}$ the density of water.

However, the Los Angeles hardness is determined in accordance with standard NF EN 1097-2 [15] in order to determine the mechanical fragmentation strength of the aggregates by shocks of elements in the rattler according to the aggregates composition (Table 1 ) provided with the abrasive load (Table 2).

The Los Angeles abrasion value is defined by the formula 3:

$L A=\frac{m}{M} \times 100$

where $m$ represent the mass of the refusal of the weighing to the sieve of $1.6 \mathrm{~mm} ; M$ the initial aggregate mass submitted for testing and $L A$ the Los Angeles abrasion value. Finally, the aggregates crushing test is carried out in accordance with the standard NF EN 1097-1 [16] from the aggregates composition as shown in Table 3. It makes it possible to determine the wear strength of the aggregates sifted the shocks of standardized mass of balls as given in 
Table 4 in the crushing apparatus by measuring the number of elements of size lower than $1.6 \mathrm{~mm}$ produced.

The aggregates crushing value is obtained by the formula 4:

$M D E=\frac{m}{M} \times 100$

where $m$ represent the mass of the refusal $1.6 \mathrm{~mm}$ sieve; $M$ is initial aggregate mass submitted for testing and $M D E$ the aggregates crushing value.

\section{Results}

\subsection{Petrographical properties of basalts}

Basalts outcrops in the form of prisms on all sides of interfluves in the Fifty One locality with the coordinate $5^{\circ} 45^{\prime} 25.7^{\prime \prime} \mathrm{N}$ and $9^{\circ} 45^{\prime} 14.8^{\prime \prime} \mathrm{E}$. They are hard, dense, compact, dark colored, essentially consisting of olivine and pyroxene of size ranging between 0.5 and $10 \mathrm{~mm}$.

The thin section of basalts expresses the microlithic porphyritic texture and constituted by plagioclase, olivine, pyroxene, and opaque minerals.

\subsubsection{Plagioclase (65-67\%)}

Plagioclase is presented in the phenocrysts forms of size ranging between 0.3 and $0.45 \mathrm{~mm}$ and of microlites of size less than $0.2 \mathrm{~mm}$. Plagioclase phenocrysts (10\%) are recognizable rods lengthened by the polysynthetic macle of white feldspar. Microlites (55\%) are presented in fine rods directed around the olivine crystals (Fig. $3 \mathrm{c}$ ).

\subsubsection{Olivine (8-9\%)}

Olivine is automorphic and shows the form of a squat and cracked prism. Other sections are equipped with many opaque minerals inclusions and present traces of weathering into serpentine (Fig. 3b).

\subsubsection{Pyroxene (9-11\%)}

Pyroxene is sub-automorphic of size not exceeding $0.2 \mathrm{~mm}$ of length and $0.15 \mathrm{~mm}$ broad (Fig. 3a).

\subsubsection{Opaque minerals (9-10\%)}

Opaque minerals are presented in the form of aggregates of size not exceeding $0.1 \mathrm{~mm}$.

\subsection{Petrographical properties of granites}

Granites outcrops in blocks of sizes varying between $30 \mathrm{~cm}$ and $1.5 \mathrm{~m}$ at the top of an interfluve in the Keunom Tiben locality between latitude $5^{\circ} 51^{\prime} 44^{\prime \prime}$ and longitude $9^{\circ} 47^{\prime} 16.9^{\prime \prime}$. In metric flagstones of sizes varying between 0.8 and $11 \mathrm{~m}$ at the top of interfluve in the Ofen Tiben locality between latitude $5^{\circ} 51^{\prime} 41^{\prime \prime}$ and longitude $9^{\circ} 46^{\prime} 45.7^{\prime \prime}$. Then in blocks and flagstones of sizes varying between $50 \mathrm{~cm}$ and $8 \mathrm{~m}$ on the slope of interfluve in the Numba locality between latitude $5^{\circ} 50^{\prime} 42.7^{\prime \prime}$ and longitude $9^{\circ} 43^{\prime} 42.7^{\prime \prime}$. They are compact, dense and massive, are presented under a milky white aspect and consist of biotite and amphibole of size ranging between 0.7 and $1.4 \mathrm{~cm}$.

The thin section of the granites has illustrated a grainy porphyritic texture and constituted by quartz, microcline, plagioclase, biotite, hornblende, opaque minerals and of zircon.
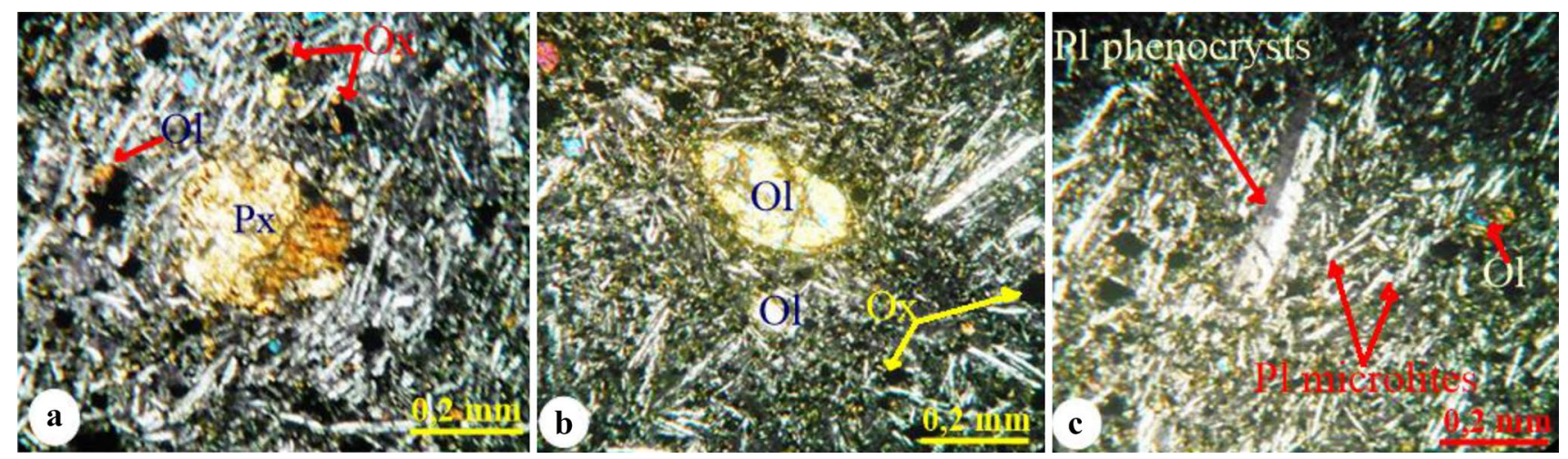

Fig. 3 Microphotography of basalts, $\mathbf{a}$ and $\mathbf{b}$ minerals of pyroxene and olivine, $\mathbf{c}$ phenocrysts and microlites of plagioclase, Ol: olivine, Px: pyroxene, Ox: opaque minerals, PI: plagioclase 

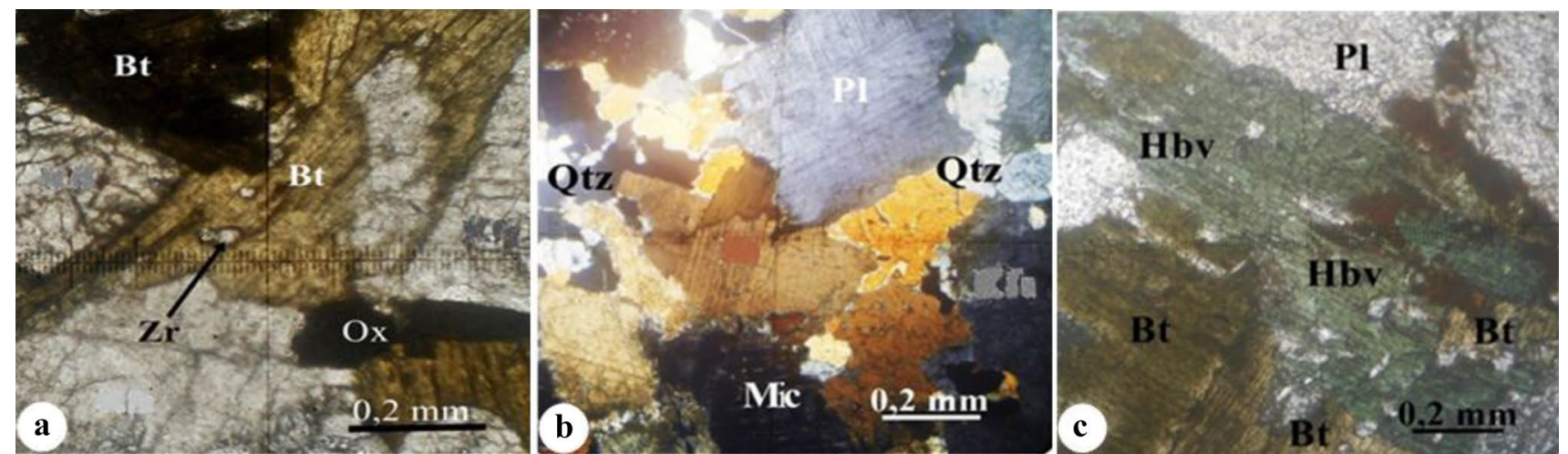

Fig. 4 Microphotography of granites, a association of biotite and opaque minerals, $\mathbf{b}$ cluster of quartz and plagioclase, $\mathbf{c}$ zircon inclusion in biotite, Bt: biotite, Zr: zircon, Ox: opaque minerals, Qtz: quartz, PI: plagioclase, Mic: microcline, Hbv: hornblende

\subsubsection{Quartz (12-13\%)}

Quartz is xenomorphic, of size less than $0.6 \mathrm{~mm}$ of length and $0.2 \mathrm{~mm}$ broad, presenting a traveling extinction (Fig. 4b). It forms a cluster mineral with microcline crystals, plagioclase and of biotite (Fig. 4b).

\subsubsection{Microcline (16-18\%)}

Microcline is sub-automorphic, is presented in the form of plates not exceeding $0.4 \mathrm{~mm}$ of length and $0.3 \mathrm{~mm}$ broad. It is marked by its chatoyant squaring characteristic and is in partnership with quartz and biotite (Fig. 4b).

\subsubsection{Plagioclase (10-12\%)}

Plagioclase sections present irregular contours, of size varying between $0.42 \mathrm{~mm}$ of length and $0.37 \mathrm{~mm}$ broad. The white feldspar macle is far from visible. It is associated with quartz (Fig. 4b).

\subsubsection{Biotite (9-11\%)}

Biotite is pleochroic in the yellowish-green and the dark green. It is presented in the form of lengthened spangle of size greater than $0.5 \mathrm{~mm}$ of length and $0.3 \mathrm{~mm}$ broad. Zircon inclusions are present there (Fig. 4c). Other sections are associated with green hornblende crystals (Fig. 4c).

\subsubsection{Hornblende (10-12\%)}

Green hornblende is presented in the lengthened form of size exceeding $0.6 \mathrm{~mm}$ of length and $0.4 \mathrm{~mm}$ broad (Fig. 4c). It is in partnership with the plagioclase crystals (Fig. 4c).

\section{SN Applied Sciences

\subsubsection{Opaque minerals (1-2\%)}

Opaque minerals are essentially secondary, resulting from the biotite destabilization. They are presented in the form of cluster, size not exceeding $0.4 \mathrm{~mm}$ of length and $0.1 \mathrm{~mm}$ broad. They are associated with the biotite (Fig. 4a).

\subsubsection{Zircon (1\%)}

Zircon has a round form in the biotite of size not exceeding $0.05 \mathrm{~mm}$ in diameter.

\subsection{Petrographical properties of gneisses}

Gneisses outcrops in metric blocks on the slope of an interfluve in the Ogwei Tiben locality. They are dense, compact, massive, and pinkish in colour and compound by the orthoclase and in amphibole pockets varying in size from $1.5 \mathrm{~cm}$ to $3 \mathrm{~cm}$.

The thin section of gneisses has a heterogranular granoblastic texture and constituted by quartz, potassium feldspar (microcline), plagioclase, biotite, amphibole and opaque minerals.

\subsubsection{Quartz (19-21\%)}

Quartz is sub-automorph with rounded contours, less than $1 \mathrm{~mm}$ of length and $0.8 \mathrm{~mm}$ broad. It forms an aggregate with green hornblende and plagioclage (Fig. 5C)

\subsubsection{Potassium feldspar (9-11\%)}

Potassium feldspar (microcline) is xenomorphic in size up to $1 \mathrm{~mm}$ of length and $0.8 \mathrm{~mm}$ broad. Some crystals have fractures. It is generally associated with quartz (Fig. 5c) 

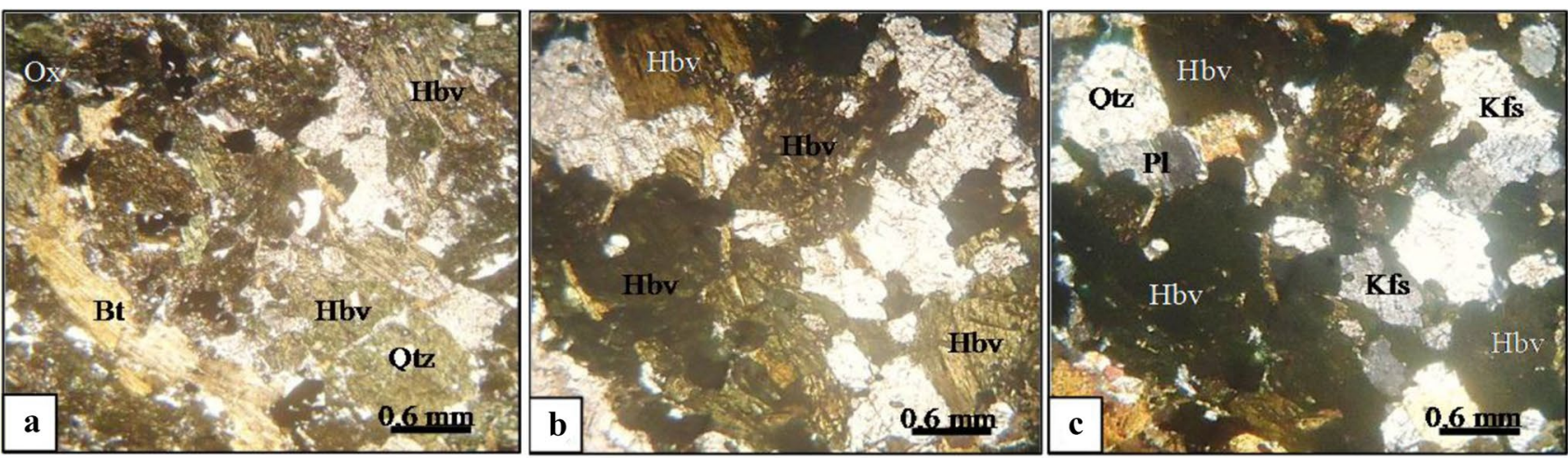

Fig. 5 Microphotography of gneisses, a association of opaque minerals with biotite, c association of amphibole with quartz and plagioclage, Ox: opaque minerals, Hbv: hornblende, Bt: biotite, Qtz: quartz, Pl: plagioclage, Kfs: potassium feldspar

\subsubsection{Plagioclase (7-9\%)}

The plagioclase has a size between $0.7 \mathrm{~mm}$ of length and $0.52 \mathrm{~mm}$ broad. It forms an aggregate with quartz and green hornblende (Fig. 5c)

\subsubsection{Biotite (13-15\%)}

Biotite is in the form of an elongated lamella with a diameter of up to $2.8 \mathrm{~mm}$ from the major axis and $0.4 \mathrm{~mm}$ from the minor axis. These lamellae are entangled with each other and associated with the green hornblende to form fine ferromagnesian levels (Fig. 5a)

\subsubsection{Amphibole (25-27\%)}

The amphibole is the green hornblende. It is sub-automorphic to xenomorphic, less than $2 \mathrm{~mm}$ of length and $1.2 \mathrm{~mm}$ broad. It is frequently associated with quartz and plagioclase (Fig. 5c)

\subsubsection{Opaque minerals ( $1 \%)$}

Opaque minerals are sub-automorphic, up to $0.25 \mathrm{~mm}$ length and $0.15 \mathrm{~mm}$ broad, and are scattered in the rock. They are in contact with biotite (Fig. 5a)

\subsection{Physical and Geomechanical characteristics of basalts, granites and gneisses}

Physical and geomechanical characteristics of studied basalts, granites and gneisses are summarized in Table 5 below.

As seen on Table 5, MB1 has a bulk density of $2.91 \mathrm{~g} / \mathrm{cm}^{3}$, a specific density of $2.88 \mathrm{~g} / \mathrm{cm}^{3}$. A Los Angeles abrasion value of $16.2 ; 15.9$ and $13.1 \%$ and an aggregate crushing value of $13.0 ; 10.7$; and $8.2 \%$ for particles size classes $4 / 6.3$; $6.3 / 10$ and $10 / 14 \mathrm{~mm}$, respectively.

Moreover, $M B 2$ has a bulk density of $2.83 \mathrm{~g} / \mathrm{cm}^{3}$, a specific density of $2.68 \mathrm{~g} / \mathrm{cm}^{3}$. A Los Angeles abrasion value of $37.2 ; 35.1$ and $29.7 \%$ and an aggregate crushing value of $15.9 ; 14.7$; and $8.9 \%$ corresponding respectively to particles size classes $4 / 6.3 ; 6.3 / 10$ and $10 / 14 \mathrm{~mm}$.

Furthermore, $M B 3$ has a bulk density of $2.84 \mathrm{~g} / \mathrm{cm}^{3}$, a specific density of $2.66 \mathrm{~g} / \mathrm{cm}^{3}$. A Los Angeles abrasion value of $44.3 ; 41.0$ and $39.1 \%$ and an aggregate crushing value of $27.5 ; 25.5$ and $20.8 \%$ for particles size classes $4 / 6.3$; $6.3 / 10$ and $10 / 14 \mathrm{~mm}$, respectively.

Finally, MB4 has a bulk density of $2.65 \mathrm{~g} / \mathrm{cm}^{3}$, a specific density of $2.61 \mathrm{~g} / \mathrm{cm}^{3}$. A Los Angeles abrasion value of $27.7 ; 30.8$ and $27.4 \%$ and an aggregate crushing value of $16.5 ; 9.5$ and $7.0 \%$ corresponding respectively to particles size classes $4 / 6.3 ; 6.3 / 10$ and $10 / 14 \mathrm{~mm}$. The histogram of
Table 5 Physical and geomechanical characteristics of studied basalts, granites and gneisses

\begin{tabular}{llllllllr}
\hline Samples & $d_{a}(\mathrm{~g} / \mathrm{cm} 3)$ & $d_{s}(\mathrm{~g} / \mathrm{cm} 3)$ & $L A(\%)$ \\
\hline$M B 1$ & 2.91 & 2.88 & 16.2 & 15.9 & 13.1 & 13.0 & 10.7 & 8.2 \\
$M B 2$ & 2.83 & 2.68 & 37.2 & 35.1 & 29.7 & 15.9 & 14.7 & 8.9 \\
$M B 3$ & 2.84 & 2.66 & 44.3 & 41.0 & 39.1 & 27.5 & 25.5 & 20.8 \\
$M B 4$ & 2.65 & 2.61 & 27.7 & 30.8 & 27.4 & 16.5 & 9.5 & 7.0 \\
\hline
\end{tabular}

$d_{a}$ bulk density, $d_{s}$ specific density, LA Los Angeles abrasion value, MDE Aggregates crushing value, MB1 basalts, MB2 fine grainy granites, $M B 3$ coarse grainy granites, $M B 4$ gneisses 

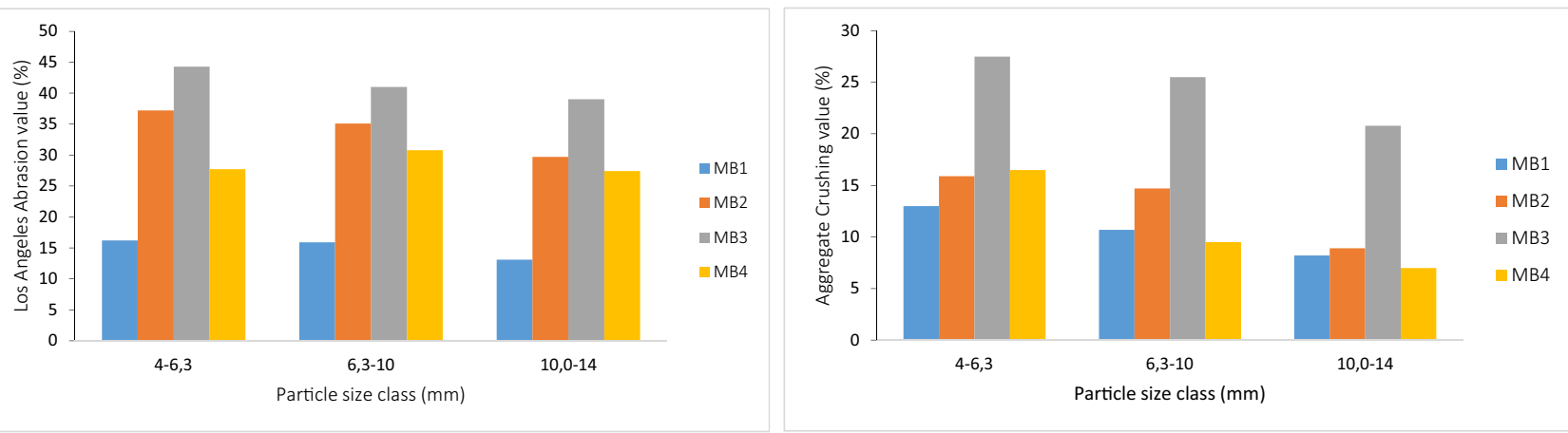

Fig. 6 Histogram of variation of the Los Angeles abrasion value and aggregates crushing value

Table 6 Guideline on assessment of the quality and the durability of the rocks

\begin{tabular}{llllll}
\hline Criteria & Reference methods & Excellent & Satisfactory & Limited & Poor \\
\hline Specific density (g/m3) & EN 13,383-2 & $>2.7$ & $2.5-2.7$ & $2.3-2.5$ & $<2.3$ \\
Los Angeles abrasion value (\%) & EN 1097-2 & $<15$ & $15-25$ & $25-35$ & $>35$ \\
Aggregate crushing value (\%) & EN 1097-1 & $<10$ & $10-20$ & $20-30$ & $>30$ \\
\hline
\end{tabular}

variation of the Los Angeles abrasion value and aggregates crushing value are shown in Fig. 6 below.

\section{Discussion}

$M B 1, M B 2, M B 3$ and $M B 4$ have a specific density of 2.88; 2.68; 2.66 and $2.61 \mathrm{~g} / \mathrm{m}^{3}$ respectively. Looking at the results $M B 1$ has a specific density greater than $2.7 \mathrm{~g} / \mathrm{cm}^{3}$. According to the reference method EN 13383-2 (Table 6), it is described as excellent material. MB2, MB3 and MB4 have a specific density ranging between 2.5 and $2.7 \mathrm{~g} /$ $\mathrm{cm}^{3}$. From these, they are qualified as satisfactory materials. A specific density of an aggregate is an important factor in mix design calculation because it relates the weight of aggregate to its volume. This property gives an idea of strength of rocks [17].

$M B 1$ has a high bulk density $\left(2.91 \mathrm{~g} / \mathrm{cm}^{3}\right)$. This high value of density connects would be related to the density of olivine included between 3.2 and $3.6 \mathrm{~g} / \mathrm{cm}^{3}$ and that of pyroxenes $\left(3.3 \mathrm{~g} / \mathrm{cm}^{3}\right)$ its principal components. In addition, MB2 and MB3 have bulk density of 2.83 and $2.84 \mathrm{~g} /$ $\mathrm{cm}^{3}$, respectively. These values could be due to the density of micas which lies between 2.7 and $3.3 \mathrm{~g} / \mathrm{cm}^{3}$ and that of the average density of the minerals $\left(2.65 \mathrm{~g} / \mathrm{cm}^{3}\right)$ main constituent of granites [18]. Rocks quality for construction materials is governed by petrographic composition, texture, particle shape, porosity, among others as given by $[19,20]$. These properties directly affect the mechanical behavior of the rock [1]. However, the petrographical examination, despite being qualitative in nature remains the most valuable test for predicting the overall performance of concrete aggregates [21].

MB1 has a Los Angeles abrasion value of $16.2 ; 15.9$ and $13.1 \%$ for particles size classes $4 / 6.3 ; 6.3 / 10$ and $10 / 14 \mathrm{~mm}$, respectively. Based on the reference method EN 1097-2 (Table 6), it is described as satisfactory to excellent material. Thus, basalts resist better to mechanical fragmentation whatever the selected particles size classes chosen. However, fine grainy granites has a Los Angeles abrasion value of $37.2 ; 35.1$ and $29.7 \%$ corresponding respectively to particles size classes $4 / 6.3 ; 6.3 / 10$ and $10 / 14 \mathrm{~mm}$. According to the reference method EN 1097-2, it is classified as poor to limited materials. Coarse grainy granites are poor in the three particles size classes $4 / 6.3 ; 6.3 / 10$ and $10 / 14 \mathrm{~mm}$. The values obtained are $44.3 ; 41.0$ and $39.1 \%$ respectively. So, strong aggregates are normally preferred because they can resist abrasion, make an excellent bond with cementing materials [22].

Studied basalts have an aggregate crushing value of 13.0; 10.7 and $8.2 \%$ for particles size classes $4 / 6.3 ; 6.3 / 10$ and $10 / 14 \mathrm{~mm}$ respectively. Based on the reference method EN 1097-1, there are classified as satisfactory to excellent materials. Concerning a fine grainy granites, they have an aggregate crushing value of $15.9 ; 14.7$ and $8.9 \%$ for particles size classes $4 / 6.3 ; 6.3 / 10$ and $10 / 14 \mathrm{~mm}$ respectively. According to the reference method EN 10971 , there are considered as satisfactory to excellent materials. Coarse grainy granites have an aggregate crushing value of $27.5 ; 25.5$ and $20.8 \%$ corresponding respectively to particles size classes $4 / 6.3 ; 6.3 / 10$ and $10 / 14 \mathrm{~mm}$. According to the reference method EN 1097-1, there are 
limited. Thus, the fine grainy rocks resist better to abrasion and crushing than the coarse grainy rocks [23].

The aggregate crushing value in the presence of water decreases with increase in the particles size classes. Thus, the lowest crushing value of an aggregate corresponds to the excellent quality of the material. Basalts offer better characteristics that of its bulk density, its Los Angeles abrasion value and its aggregate crushing value whatever the particles size classes in which it is studied. For these reasons, [24-27] use basalts aggregates to improve the geotechnical characteristics of fine lateritic soils. In the same vein, Hyoumbi et al. [28] shows that in general, the additions of $20 \%$ to $50 \%$ of $0 / 5 \mathrm{~mm}$ basalt aggregates to fine lateritic soils moderately modify their physical properties such as: particle size, Atterberg limits and values in methylene blue. Compared to the fine grainy granites, coarse grainy granites which are more unstable due to weathering. The volcanic rocks have better mechanical characteristics than the plutonic ones with an equal mineralogical composition [29]. Therefore, volcanic rocks have been widely used in various industrial applications in many parts of the world but the most widespread applications is in the construction industry as crushed aggregates and building stone for various civil structures [1].

Moreover, the more the size of the basalts crystals increases, the more their Los Angeles abrasion value and aggregate crushing value are excellent. In addition, there are used extensively as engineering materials throughout the world as aggregates for cement and asphalt concrete mix, airfield pavement construction, rock fill for dams and breakwaters, materials for rail road ballast and high way base courses [30]. They can also be using as building stone (cobblestone, wall claddings, cladding stone) [1].

\section{Conclusion}

This research has concerning the petrographical and geomechanical characterization of geological formations like basalts, granites and gneisses from North-West Cameroon for their potential use as construction materials. The petrographical analysis has shown that, basalts have microlithic porphyritic texture and constituted by feldspar (plagioclase), olivine, pyroxene and opaque minerals. Granites show in microphotography the grainy porphyritic texture and dominated by quartz, feldspar (plagioclase, microcline), biotite and hornblende minerals. Gneisses illustrated a heterogranular granoblastic texture and constituted by quartz, feldspar (orthoclase, plagioclase), biotite, amphibole and opaque minerals. The geomechanical properties of those geological formations illustrate an increasing correlation between the Los Angeles abrasion value, the aggregates crushing value and the size of the particles classes $(4 / 6.3 ; 6.3 / 10$ and $10 / 14 \mathrm{~mm})$. The geomechanical results close to international recommendation. Therefore, they can be used like raw materials in rail road ballast, high way base courses or component of concrete, aggregates for bituminous road and pavement.

Funding This project was funded personally by the authors.

Data availability The data used this current study are available from the corresponding author on upon request.

\section{Compliance with the ethical standards}

Conflict of interest The authors declare that there is no conflict of interest.

\section{References}

1. Tesfaye AE, Asmelash A (2016) Assessment and evaluation of rocks used as construction materials in the City of Addis Ababa. Momona Ethopian J Sci (MEJS), V8(2): 193-212 CNCS, Mekelle University and ISSN: 2220-184X.

2. Berthonneau J (2013)Le rôle des minéraux argileux dans la dégradation de la pierre : application à la conservation de la « pierre du midi » en termes de durabilité et compatibilité des matériaux en œuvre Université d'Aix Marseille Thèse de Doctorat p. 377

3. Katte VY, Yemeli CM, Kenmoe ORM (2020) Wouatong ASL (2019) Pavement dimensioning with and on lateritic materials of the Mbu-Baforchu area. SN Appl Sci 2:121. https://doi.org/10.1007/ s42452-019-1865-6

4. Paul TM (2011) Conception et réalisation des structures routières à hautes performances Université Politehnica de Timisoara Thèse de Doctorat p. 73

5. Houga A, Saltana A (2014) Contribution à la valorisation des potentiels locaux en granulats de la région d'Ouargla par les méthodes géotechniques Université Kasdi Merbah Mémoire de fin d'études p. 73

6. Bessaoudi B, Djellali N (2015) Caractérisation d'un massif rocheux et étude de stabilité des talus; cas de la carrière d'AdrarOufarnou Mémoire de fin d'études. Université Abderrahmane Mira de Bejaia Algérie p. 90

7. Gountié Dedzo, Nedelec A, Nono A, Njanko T, Font E, Kamgang $P$, Njonfang $E$, Kagou Dongmo A, Nkouathio DG, Pouclet A, Bardintzeff JM, Wandji P (2010) The discovery of late Quaternary basalts on mount Bambouto: implication for recent widespread volcanic activity in the Southern Cameroon Line.

8. Moundi A, Wandji P, Bardintzeff JM, Ménard JJ, Okono Atouba LC, Farouk Mouncherou O, Reusser E, Bellon H, Tchoua FM (2007) Les basaltes Eocène à affinité transitionnelle du plateau Bamoun, témoin d'un réservoir mantellique enrichi sous la ligne volcanique du Cameroun. C R Géosciences 339:831-837

9. Fosso J, Menard JJ, Bardintzeff JM, Wandji P, Tchoua FM, Bellon $H$ (2005) Les laves du mont Bangou : une première manifestation volcanique éocène à affinité transitionnelle de la ligne du Cameroun. C.R. Geosci 337:315-325 
10. Gountié DM, Nono A, Njonfang E, Kamgang $P$, Zangmo TG, Kagou DA (2011) Nkouathio DG (2011) Le volcanisme ignimbritique des monts Bambouto et Bamenda (Ligne du Cameroun, Afrique Centrale): signification dans la genèse des caldeiras. Bull de I'Inst Sci Rabat, Sec Sci de la Terre 33:1-15

11. Tchoua FM (1974) Contribution à l'étude géologique et pétrographique de quelques volcans de la ligne du Cameroun (monts Manengouba et Bambouto) Université de Clermont-ferrand Thèse de Doctorat d'état p. 337

12. Kamgang $P$ (2003) Pétrologie et géochimie d'un secteur clé de la ligne du Cameroun, les monts Bamenda: implications sur la génèse et l'évolution des magmas Etat, Univ. Ydé I Thèse Doct p. 373

13. Norme NF P $18-554$ et NF P $18-555$ (1990) Sols, reconnaissance et essais: détermination du poids spécifique.

14. Norme NF P 94 - 054 (1991) Sols, reconnaissance et essais: détermination de la densité apparente.

15. Norme NF EN 1097 - 2 (1998) Roches, reconnaissance et essais: détermination de la fragmentation mécanique.

16. Norme NF EN 1097 - 1 (1996) Roches, reconnaissance et essais: détermination de la résistance à l'usure.

17. Al-Akhaly IA (2018) Engineering properties of basalts coarse aggregates in Hamdan area, NW Sana'a, Yemen. Journal of Geological Engineering 42:159-174

18. El Hassani I-E, El Azhari H (2009) Evaluation des propriétés physico-mécaniques des pierres de construction du Maroc à partir des vitesses des ondes $\mathrm{P}$ et de la résistance au choc. Bull de l'Inst Sci Rabat Sec Sci de la Terre 31(41):54

19. Ramsay DM, Dhir RK, Spence IM (1974) The role of rock and clast fabric in the physical performance of crushed rock aggregate. Eng Geol 8:267-285

20. Smith MR, Collis L (2001) Aggregates: sand, gravel and crushed rock aggregates for construction purposes. Geol Soc Eng Geol Special Publ 17:339

21. Berubé MA (2001) Mineralogical and petrographic analysis of concrete aggregates. J Mater Metals Materials Soc (TMS) 53(12):45-47
22. BS 812: part 112. (1990) Methods for determination of aggregate impact value (AIV) British Standards Institution London, UK

23. Schoeder C (1975) Intérêt d'une définition géologique complète en mécanique des roches. Ann. Soc. Géol. Belg. T 98:405-413

24. Ampardu KIS, Fiadjoe YJG (2015) Influence of water content on the Dynamic Cone Penetration Index of a lateritic soil stabilized with various percentages of a quarry product. Transp Geotech 5:68-85

25. Frempong EM, Tsidzi NEK (1999) Blending of marginally suitable tropical sub-base materials for used in base course construction. J. Construc Building Mater 13:129-141

26. Madjadoumbaye J, Ngapgue F, Nouanga P, Abdou CM, Tamo TT (2012) Improving the bearing capacity of laterite by adding sand. EJGE 17:23-32

27. Okagbue CO, Onyeobi SUT (1999) Potential of marble dust to stabilize red tropical soils for road construction. J Eng Geol 53:371-380

28. Hyoumbi TW, Pizette P, Wouatong ASL, Nor-Edine A, Borrel LR, Norotiana RF, Ngapgue F, Guouillier T (2018) Influence des granulats basaltiques $0 / 5$ sur les propriétés géotechniques des sols fins latéritiques de Bafang (Ouest-Cameroun) en vue de leur valorisation en technique routière. Journées Nationales de Géotechnique et de Géologie de l'Ingénieur - Champs-sur-Marne.

29. Eynde PV (1977) Caractéristiques géologiques et mécaniques des granulats. Mémoire présenté en réponse à la $6^{\mathrm{e}}$ question du concours annuel.

30. Goodman RE (1992) Engineering Geology: Rocks in Engineering Construction, 2nd edn. Wiley, New York, p 562p

31. Belmihoud H (2009) Influence de la dimension fractale sur la perméabilité. Mémoire de Magister en génie civil. Université Mouloud Mammeri de Tizi Ouzou. Algérie. 80p.

Publisher's Note Springer Nature remains neutral with regard to jurisdictional claims in published maps and institutional affiliations. 